\title{
THE POWER TO REMOVE COMPANY DIRECTORS FROM OFFICE: HISTORICAL AND PHILOSOPHICAL ROOTS
}

\author{
Rehana Cassim*
}

\section{ABSTRACT}

The Companies Act 71 of 2008 introduced into South African law a provision that, for the first time, empowers the board of directors to remove a director from office. This article contends that the novel power conferred on the board to remove a director from office represents a fundamental shift in the balance of power between shareholders and directors. This article traces the historical division of powers between the board and shareholders in South African law, as well as in the United Kingdom, Australia and the United States of America. It also explores the historical reasons and underpinning philosophy as to why the shareholders acting in a shareholders' meeting have been conferred the right, by means of an ordinary resolution, to remove directors from office in these jurisdictions. The article further explores the full implications of this new power granted under the Companies Act 71 of 2008. It is further significant that section 66(1) of the Companies Act 71 of 2008 represents the first instance in South Africa's company law history of statutorily conferring original powers of management on the board. It is argued that, despite the qualifications attached to it, this power of removal conferred on the board of directors has significantly shifted

* $\quad$ BA (cum laude) LLB (cum laude) LLM (cum laude) (Witwatersrand) LLD (Unisa). Senior Lecturer, Department of Mercantile Law, School of Law, University of South Africa, Attorney and Notary Public of the High Court of South Africa. This article is based on sections of the author's LLD thesis. 
the balance of power and dynamics not only between the board of directors and the shareholders, but also between the shareholders themselves, and even between the directors inter se. Some suggestions are made with regard to containing the shift in the balance of power between directors and shareholders.

Keywords: Division of powers between directors and shareholders; separation of ownership and control; balance of powers between directors and shareholders; removal of directors from office; corporate democracy

\section{Introduction}

The Companies Act 71 of 2008 ("the Companies Act") came into force on 1 May 2011. It introduced into South African law a provision that, for the first time, empowers the board of directors to remove a director from office. This provision is contained in section 71(3), and it permits the board, on certain grounds and subject to a right of review, ${ }^{1}$ to remove a director from office in certain instances. ${ }^{2}$ Previously, under the repealed Companies Act 61 of 1973, only the shareholders acting in a shareholders' meeting - and not the board of directors - were statutorily empowered to remove a director from office. ${ }^{3}$ This article contends that the novel power, conferred by section 71(3) of the Companies Act on the board to remove a director from office, represents a fundamental shift in the balance of power between shareholders and directors. It is further significant that section 66(1) of the Companies Act represents the first instance in South Africa's company law history of statutorily conferring original powers of management on the board.

This article traces the historical division of powers between the board and the shareholders in both South African law and the law of the United Kingdom ("UK"), which has always had a strong influence on South African company law. The legal position in Australia and in the United States of America ("USA") is also discussed. In addition, this article explores the historical reasons and the underpinning philosophy

1 See s 71(5) of the Companies Act, which allows a director who has been removed from office by the board of directors, or a person who appointed that director as contemplated in s 66(4)(a)(i) of the Companies Act, to apply to a court, within twenty business days, to review the decision of the board.

2 These instances are where a shareholder or director has alleged that a director of the company has become ineligible, disqualified, incapacitated, or has neglected or been derelict in the performance of the functions of director.

3 It is noteworthy that under s 219(1) of the Companies Act 61 of 1973, a court was empowered to make an order in certain circumstances directing that, for the period specified in the order, a director could not, without the leave of the court, be a director or in any way be concerned with or take part in the management of a company. It was observed by Cilliers \& Benade 2002: 126 that s 219 of the Companies Act 61 of 1973 was in "disuse" in South Africa and that there were no reported cases regarding that provision. 
as to why the shareholders, acting formally and collectively, were granted the right to remove one or more directors from office in these jurisdictions. The full implications of the new power conferred by the Companies Act are explored. It is argued that this power has significantly shifted the balance of power and dynamics, not only between the board of directors and the shareholders acting in a shareholders' meeting, but also between the shareholders themselves, and even between the directors inter se. Some suggestions are made with regard to containing the shift in the balance of power between directors and shareholders. While a director has a right to challenge his or her removal from office under section $71(4)(b)^{4}$ of the Companies Act or to apply, under section 71(5) of the Companies Act, for a review of the board's decision to remove him or her from office, and further may have a right to claim damages or other compensation for loss of office under section 71(9) of the Companies Act, ${ }^{5}$ the focus of this article is not on these rights or remedies. Instead, the focus of this article is on the implications of the new power conferred on the board of directors to remove fellow directors from office.

\section{The division of powers between directors and shareholders}

The common-law division of powers between the board of directors and the shareholders in a general meeting (now called "a shareholders' meeting") must be distinguished from the statutory division of powers. This is discussed below.

\section{The common-law division of powers}

The powers of a company are divided between the board of directors and the shareholders in a shareholders' meeting, and each organ has its own separate sphere of power. ${ }^{6}$ Until the end of the nineteenth century, it was generally accepted that the general meeting was the personification of the company and the supreme organ

4 Section 71(4)(b) of the Companies Act gives the director a reasonable opportunity to make a presentation, in person or through a representative, to the board meeting before the resolution for his or her removal is put to the vote by the board of directors.

5 Section 71(9) confers on a director, who is removed from office under s 71 of the Companies Act, a right to apply to a court for damages or other compensation for loss of office as a director, or for loss of any other office as a consequence of being removed as a director.

6 Automatic Self-cleansing Filter Syndicate Company Limited v Cuninghame [1906] 2 Ch 34 (CA); The Gramophone \& Typewriter Ltd v Stanley [1908] 2 KB 89 (CA); Salmon v Quin and Axtens Ltd [1909] 1 Ch 311 (CA); John Shaw \& Sons (Salford) Ltd v Peter Shaw \& John Shaw [1935] 2 KB 113 (CA) at 134; Scott v Scott [1943] 1 All ER 582 (ChD); Cape United Sick Fund Society v Forrest 1956 (4) SA 519 (A); Wessels \& Smith v Vanugo Construction (Pty) Ltd 1964 (1) SA 635 (O) at 637; Van Tonder v Pienaar 1982 (2) SA 336 (SE) at 341; Breckland Group Holdings Ltd v London \& Suffolk Properties Ltd [1989] BCLC 100 (ChD); Ben-Tovim v Ben-Tovim 2001 (3) SA 1074 (C) at 1085-1086; Massey v Wales (2003) 177 FLR 1 (Austl) at 12. 
of the company, and that the directors were simply agents subject to the control of the company (i.e. the shareholders) in general meeting. ${ }^{7}$ Since the powers conferred upon the directors (as the agents) were thought of as having been conferred upon them by the shareholders (as the principals), it was deduced that the directors were subject to the control of the shareholders in general meeting. ${ }^{8}$ The implication was that the shareholders could at any time by ordinary resolution give the directors instructions on how they were to exercise their powers of management. ${ }^{9}$

This view of the superiority of the shareholders appears to be derived from the influence of elements of the law of partnership. ${ }^{10}$ Historically, in 1837, there were two principal vehicles used to conduct businesses on a large scale - the corporation and the joint stock company. ${ }^{11}$ The corporation existed in terms of a Royal Charter ${ }^{12}$ or an Act of Parliament ${ }^{13}$ and had a separate legal existence, while the joint stock company was simply a large partnership and did not enjoy a separate legal existence. ${ }^{14}$ Joint stock companies were economically the more important vehicle and courts applied the principles of partnership in regulating them. ${ }^{15}$ The application of partnership principles to joint stock companies, however, posed difficulties, because typical joint stock companies had hundreds of members, and it was clear that there was no personal relationship between the members, as is the case in a partnership. ${ }^{16}$ In order to address these problems, the Joint Stock Companies Act, $18444^{17}$ was enacted. This was the first Companies Act to provide for incorporation by registration, and it empowered the Registrar of Joint Stock Companies to incorporate a company whose documents were registered with him or her. ${ }^{18}$ This Act limited the size of partnerships, thus forcing large joint stock ventures to adopt a corporate form. ${ }^{19}$ Nevertheless, the courts continued to invoke partnership principles to resolve company law matters

7 Isle of Wight Railway Co v Tahourdin (1883) 25 ChD 320 (CA); Cilliers \& Benade 2002: 85; Keay 2007: 657; Davies \& Worthington 2016: 358.

8 Aickin 1967: 449.

9 Davies \& Worthington 2016: 358-359.

10 Aickin 1967: 449.

11 See Grantham 1998: 557, where these two vehicles are discussed.

12 Companies incorporated by a Royal Charter were known as "chartered companies". The members contributed capital to form the companies" "joint stock", which was then managed by governors or directors appointed by the members (see French, Mayson \& Ryan 2015: 7).

13 Parliament could create a body corporate by an enactment that referred specifically to that body corporate (French, Mayson \& Ryan 2015: 7).

14 Grantham 1998: 557-558; French, Mayson \& Ryan 2015: 7.

15 Grantham 1998: 558.

16 Ibid.

$17 \quad 7$ \& 8 Vict c 110.

18 Kershaw 2012: 489. Registration took place in two stages, namely a provisional registration and a complete registration. The system was revised by the Joint Stock Companies Act of 1856, which introduced a single-stage registration system (see French, Mayson \& Ryan 2015: 8).

19 Grantham 1998: 558. 
and a company was still regarded as a peculiar kind of partnership. ${ }^{20}$ The status of shareholders in company law at the time was that they were the ultimate proprietors of the company, and entailed that they had the right to manage the company and to have the company run for their exclusive benefit. ${ }^{21}$

The superiority of the shareholders was enunciated in one of the first cases dealing with the relative positions of the general meeting and the directors, namely Isle of Wight Railway Co v Tahourdin. ${ }^{22}$ In this case, the directors called a shareholders' meeting on a requisition by the shareholders, but the notice of the meeting issued by the directors did not provide for all the objects of the requisitionists. The requisitionists notified the directors that they would not attend the shareholders' meeting called by the directors, and subsequently issued a notice calling their own meeting. The directors applied for an injunction restraining the requisitionists from calling their own meeting. The court a quo granted the injunction, but the UK Court of Appeal reversed the decision, and discharged the injunction. The latter court, per Cotton LJ, held that the company's shareholders in general meeting "undoubtedly [had] a power to direct and control the board in the management of the affairs of the company". ${ }^{23}$

Isle of Wight Railway Co v Tahourdin ${ }^{24}$ concerned a company established by an Act of Parliament and subject to the provisions of the Companies Clauses Consolidation Act, 1845 ( 8 \& 9 Vict c 16). Section 90 of that Act provided that the directors had powers of management and superintendence of the affairs of the company and that the exercise of such powers was subject to the control and regulation of any general meeting specially convened. ${ }^{25}$ It follows that the abovequoted statement by Cotton LJ was a reference not to the powers of the general meeting, but to the powers of control expressly conferred on the shareholders by the Companies Clauses Consolidation Act, 1845. Nevertheless, on the strength of Isle of Wight Railway Co v Tahourdin, ${ }^{26}$ the view was held that in relation to all companies, including those incorporated under the then Companies Act, 1862, the position was the same as that prevailing under the Company Clauses Consolidation Act, 1845 and

20 See, for example, In re Yenidje Tobacco Company Ltd [1916] 2 Ch 426 (CA), where the UK Court of Appeal, in deciding whether it was just and equitable that a private company be wound up, decided the matter on the basis of the principles that apply to a partnership. The court rationalised its approach on the ground that the company was in substance a partnership in the guise of a private company (at 431-432). See, further, Hill 2000: 42-43 for a discussion of the partnership model of the corporation in the nineteenth century.

21 Grantham 1998: 559; Hill 2000: 42-43.

22 (1883) 25 ChD 320 (CA).

23 Idem at 331-332.

24 Ibid.

25 See, further, Automatic Self-cleansing Filter Syndicate Company Limited v Cuninghame [1906] 2 Ch 34 (CA) at 46, where the Chancery Division discussed s 90 of the Companies Clauses Consolidation Act of 1845 .

26 (1883) 25 ChD 320 (CA). 
that a company in a general meeting had the power to direct and control the board of directors in relation to the conduct of the company's affairs. ${ }^{27}$

After the nineteenth century, however, there was a fundamental shift in the perception of the relationship between the general meeting and the directors. The notions that shareholders had the right to override decisions of management, or that the company was conducted for the exclusive benefit of the shareholders, were rejected.$^{28}$ The general rule developed to rather provide that, unless expressly empowered to do so by the constitution of the company, the shareholders in general meeting could not control the directors' exercise of their powers, nor exercise the powers conferred on the directors. ${ }^{29}$ Insofar as Isle of Wight Railway Co v Tahourdin ${ }^{30}$ held that the directors are bound by the instructions of the shareholders' meeting in carrying out their functions, this decision was no longer regarded as good law. ${ }^{31}$

In the seminal case of Automatic Self-cleansing Filter Syndicate Company Limited $v$ Cuninghame, ${ }^{32}$ the question before the UK Court of Appeal was whether the shareholders acting in a shareholders' meeting had the power to direct the course of action to be pursued by the directors (in casu, that certain assets of the company be sold) or whether the directors could refuse to do what the shareholders in a shareholders' meeting directed them to do. The constitution of the Automatic Selfcleansing Filter Syndicate Company Limited empowered the company to sell its undertaking to another company having similar objects. The directors of the former company were empowered to sell or otherwise deal with any of the company's property on such terms as they might think fit. A resolution was passed by the shareholders of the company for the sale of the company's assets on certain terms to a new company formed for the purpose of acquiring such assets, and directing the directors to carry the sale into effect. The directors were of the opinion that the sale of the company's assets on the proposed terms would not benefit the company. The directors accordingly refused to carry the sale into effect. The UK Court of Appeal held that, on the construction of the constitution of the company itself, which provided that the management of the business and control of the company was vested

27 See Aickin 1967: 451.

28 See Grantham 1998: 560-578, where the gradual attenuation of the rights of shareholders is traced in detail.

29 Automatic Self-cleansing Filter Syndicate Company Limited v Cuninghame [1906] 2 Ch 34 (CA); The Gramophone \& Typewriter Ltd v Stanley [1908] 2 KB 89(CA); Salmon v Quin and Axtens Ltd [1909] 1 Ch 311 (CA); John Shaw \& Sons (Salford) Ltd v Peter Shaw \& John Shaw [1935] 2 KB 113 (CA) at 134; Scott v Scott [1943] 1 All ER 582 (ChD); Breckland Group Holdings Ltd v London \& Suffolk Properties Ltd [1989] BCLC 100 (ChD); Goldberg 1970: 177; Blackman 1975: 286; Sullivan 1977: 569.

30 (1883) 25 ChD 320 (CA).

31 See Cilliers \& Benade 2002: 85.

32 [1906] 2 Ch 34 (CA). 
in the directors, the directors could not be compelled to comply with the resolution of the shareholders. ${ }^{33}$ The UK Court of Appeal distinguished this case from Isle of Wight Railway Co v Tahourdin ${ }^{34}$ on the basis that the Companies Clauses Act, 1845 was not applicable to the case before it and held that it was therefore not bound by the dictum of this case. ${ }^{35}$ The court emphatically rejected the notion that directors are merely agents of the general meeting, susceptible to direction by the general meeting on any matter. ${ }^{36}$

In The Gramophone \& Typewriter Ltd $v$ Stanley, ${ }^{37}$ the UK Court of Appeal approved the dictum in Automatic Self-cleansing Filter Syndicate Company Limited $v$ Cuninghame $^{38}$ and asserted that shareholders could not, even by a majority at a general meeting, interfere with the exercise of powers placed in the hands of the directors by the constitution of the company. Buckley LJ stressed that directors are not servants to obey directions given by the shareholders and that they are not agents appointed by and bound to serve the shareholders as their principals. ${ }^{39}$ To the contrary, Buckley LJ held that directors are persons who may, by the regulations, be entrusted with the control of the business and who may be dispossessed of that control only by the alteration of the company's constitution. ${ }^{40}$

Despite these authorities, the matter was not fully settled. In Marshall's Valve Gear Co Ltd v Manning, Wardle \& Co $L t d,{ }^{41}$ a different view was adopted. The Chancery Division, per Neville J, asserted that the prevailing principle was that, in the absence of any contract to the contrary, the majority of the shareholders in a company had the ultimate control of its affairs and could assert their rights in a shareholders' meeting. ${ }^{42}$ In spite of this judgement, the UK Court of Appeal in Salmon $v$ Quin and Axtens $L t d,{ }^{43}$ reverted to the position that it had previously held and adopted the view enunciated in The Gramophone \& Typewriter Ltd $v$ Stanley, ${ }^{44}$ namely that directors are persons who may - by the regulations - be entrusted with the control of the business and who may be dispossessed of that control only by the alteration of the company's constitution. The UK Court of Appeal, in Salmon v Quin and Axtens $L t d,{ }^{45}$ stated that any other construction would be disastrous, because it

33 Idem at 45.

34 (1883) 25 ChD 320 (CA).

35 Automatic Self-cleansing Filter Syndicate Company Limited v Cuninghame [1906] 2 Ch 34 (CA) at 46 .

36 Idem at $42-43$.

37 [1908] 2 KB $89(\mathrm{CA})$ at 98.

38 [1906] 2 Ch 34 (CA).

39 The Gramophone \& Typewriter Ltd v Stanley [1908] 2 KB 89 (CA) at 105-106.

40 Idem at 106.

41 [1909] $78 \mathrm{LJ}$ Ch 46 (ChD).

42 Idem at 49

43 [1909] 1 Ch 311 (CA) at 319.

44 [1908] $2 \mathrm{~KB} 89$ (CA) at 106.

45 [1909] 1 Ch 311 (CA) at 319-320. 
"might lead to an interference by a bare majority very inimical to the interests of the minority who had come into the company on the footing that the business should be managed by the board of directors". The dictum in Marshall's Valve Gear Co Ltdv Manning, Wardle \& Co Ltd ${ }^{46}$ was not referred to in Salmon v Quin and Axtens Ltd, ${ }^{47}$ but counsel for the plaintiff criticised the latter decision as being inconsistent with the principles established in Automatic Self-cleansing Filter Syndicate Company Limited $v$ Cuninghame ${ }^{48}$ and The Gramophone \& Typewriter Ltd $v$ Stanley ${ }^{49}$

Thereafter, the relationship between the board of directors and the general meeting was regarded as having been settled by the UK Court of Appeal. ${ }^{50}$ The relationship between directors and shareholders is succinctly expressed by the UK Court of Appeal in John Shaw \& Sons (Salford) Ltd v Peter Shaw \& John Shaw ${ }^{51}$ as follows:

If powers of management are vested in the directors, they and they alone can exercise these powers. The only way in which the general body of the shareholders can control the exercise of the powers vested by the articles in the directors is by altering their articles or, if opportunity arises under the articles, by refusing to re-elect the directors of whose actions they disapprove.

In Scott $v$ Scott, ${ }^{52}$ the Chancery Division said that the division of powers between the shareholders and directors is important even in the case of family companies. That court held that a resolution of shareholders purporting to interfere with the management of directors was invalid. ${ }^{53}$ The Privy Council emphasised in Howard Smith Ltd v Ampol Petroleum Ltd ${ }^{54}$ that the majority of shareholders cannot control directors in the exercise of their management powers while they remain in office. In Breckland Group Holdings Ltd v London \& Suffolk Properties Ltd, ${ }^{55}$ the Chancery Division held that the jurisdiction to conduct the business of the company was vested in the board of directors, and that the shareholders in a shareholders' meeting could not intervene in such matters.

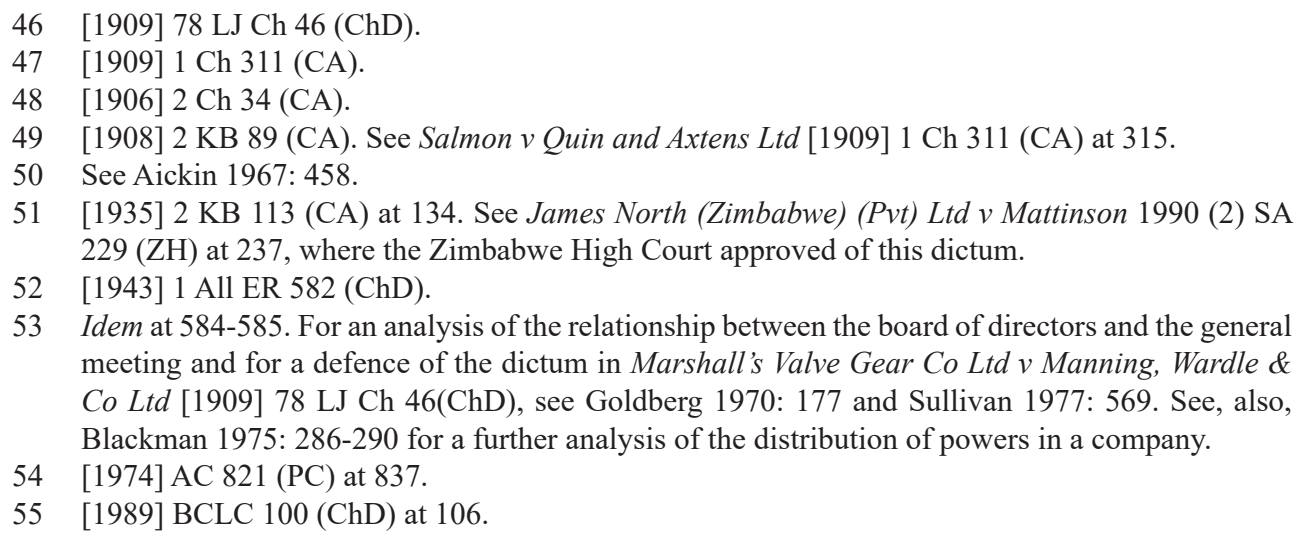

53 Idem at 584-585. For an analysis of the relationship between the board of directors and the general meeting and for a defence of the dictum in Marshall's Valve Gear Co Ltd v Manning, Wardle \& Co Ltd [1909] 78 LJ Ch 46(ChD), see Goldberg 1970: 177 and Sullivan 1977: 569. See, also, Blackman 1975: 286-290 for a further analysis of the distribution of powers in a company.

54 [1974] AC $821(\mathrm{PC})$ at 837.

55 [1989] BCLC $100(\mathrm{ChD})$ at 106. 
The distribution of power between the board of directors and the shareholders in South African law has been influenced by the position adopted by the UK courts. For instance, with regard to a friendly association endowed with legal personality under the common law, the Appellate Division in Cape United Sick Fund Society $v$ Forrest $t^{56}$ approved and applied the principle of the division of powers between managing bodies and a meeting of members. The Appellate Division further approved the principles established in Salmon v Quin and Axtens Ltd ${ }^{57}$ and John Shaw \& Sons (Salford) Ltd v Peter Shaw \& John Shaw. ${ }^{58}$ In Wessels \& Smith v Vanugo Construction (Pty) Ltd ${ }^{59}$ the Orange Free State High Court stated, with reference to and with approval of the decision in Scott $v$ Scott ${ }^{60}$ that it had already been held that an article in the constitution of a company, which provided that the business of the company shall be managed by the directors, entailed that the entire management of the company rests solely in the hands of the directors. The court consequently stated that any resolution by the company in a shareholders' meeting purporting to interfere with this management, was invalid. ${ }^{61}$ In Van Tonder v Pienaar, ${ }^{62}$ the South-Eastern Cape High Court relied on and agreed with John Shaw \& Sons (Salford) Ltd v Peter Shaw \& John Shaw ${ }^{63}$ that if powers of management are vested in the directors, they and they alone can exercise those powers.

More recently, in LSA UK Ltd (formerly Curtainz Ltd) v Impala Platinum Holdings Ltd, ${ }^{64}$ the Supreme Court of Appeal ("SCA") affirmed the general position enunciated in John Shaw \& Sons (Salford) Ltd v Peter Shaw \& John Shaw. ${ }^{65}$ The

561956 (4) SA 519 (A). The members of the Cape United Sick Fund Society had requested the board of management of the society to convene a special general meeting to consider certain resolutions that had the effect of conferring power on a body other than the board of management, of empowering a body other than the board of management to obtain legal advice, and of suspending the payment of honoraria to members of the board of management. The board of management refused to convene such a meeting. The members of the society issued a declaration claiming an order directing the board to convene such a meeting or alternatively authorising the members to call the meeting in the name of the society. The society and the members of the board excepted to the declaration as disclosing no cause of action in that under the society's constitution it would not be competent for the special general meeting to pass the proposed resolution, or, if the resolutions were passed, they would have no force or effect. The Appellate Division held that all the resolutions proposed to be moved would be ultra vires the constitution of the society, and that the board was accordingly entitled to refuse to convene the meeting.

57 [1909] 1 Ch $311(\mathrm{CA})$ at 319

58 [1935] 2 KB 113 (CA) at 134. See Cape United Sick Fund Society v Forrest 1956 (4) SA 519 (A) at 540 .

$591964(1)$ SA $635(\mathrm{O})$ at 637.

60 [1943] 1 All ER 582 (ChD).

61 Wessels \& Smith v Vanugo Construction (Pty) Ltd 1964 (1) SA 635 (O) at 637.

$621982(2)$ SA $336(\mathrm{SE})$ at 341.

$63[1935] 2 \mathrm{~KB} 113(\mathrm{CA})$ at 134.

642000 JDR 0187 (SCA).

65 [1935] $2 \mathrm{~KB} 113(\mathrm{CA})$ at 134. 
court affirmed that the board of directors and the general meeting are both organs of the company, each having its own original powers, and that the directors do not receive their powers as agents of the company. ${ }^{66}$ Accordingly, the court held, in the absence of a contrary provision in the constitution of the company, that even a unanimous resolution of the general meeting does not override the directors' powers. ${ }^{67}$ The SCA said that it is possible for the board and the general meeting to have concurrent powers, but stated that courts are disinclined to treat managerial and executive powers as concurrent and that, unless the constitution provides otherwise, these powers are exercisable exclusively by the directors. ${ }^{68}$ In Ben-Tovim v BenTovim ${ }^{69}$ the Cape High Court acknowledged that the "pendulum of the division of powers between the general meeting and the board of directors has through the years swung from the general meeting as the supreme organ to prominence of the articles of association".

\section{The statutory division of powers}

Under neither the Companies Act 46 of $1926,{ }^{70}$ nor the Companies Act 61 of 1973 , did directors have original powers. Their powers were delegated to them by the shareholders in the then articles of association of the company. A typical provision in the articles of association under the Companies Act 61 of 1973 adopted article 59 of Table A (articles for a public company having a share capital) or article 60 of Table $\mathrm{B}$ (articles for a private company having a share capital), which reads as follows:

\footnotetext{
The business of the company shall be managed by the directors who may pay all expenses incurred in promoting and incorporating the company, and may exercise all such powers of the company as are not by the Act, or by these articles, required to be exercised by the company in general meeting, subject to these articles, to the provisions of the Act, and to such regulations, not inconsistent with the aforesaid articles or provisions, as may be prescribed by the company in general meeting, but no regulation prescribed by the company in general meeting shall invalidate any prior act of the directors which would have been valid if such regulation had not been made.
}

It is evident from the above provision that, under the Companies Act 61 of 1973, the power to manage the company's affairs had to be delegated to the board of directors by the shareholders in general meeting or by the articles of association of the company. If no powers were granted to the board of directors by the articles of

66 LSA UK Ltd (formerly Curtainz Ltd) v Impala Platinum Holdings Ltd 2000 JDR 0187 (SCA) at 38.

67 Ibid.

68 Ibid.

692001 (3) SA 1074 (C) at 1085-1086.

70 See art 83 of Table A (Regulations for Management of a Company Limited by Shares) contained in Schedule 1 of the Companies Act 46 of 1926. 
association, the board would be powerless to act and the company could act only through its shareholders. ${ }^{71}$

Section 66(1) of the current Companies Act represents a fundamental change in the philosophy of the balance of power between the directors and shareholders. The section provides as follows:

The business and affairs of a company must be managed by or under the direction of its board, which has the authority to exercise all of the powers and perform any of the functions of the company, except to the extent that this Act or the company's Memorandum of Incorporation provides otherwise.

With the enactment of section 66(1) of the Companies Act, original power to manage the business and affairs of the company has, for the first time, been statutorily granted to the board of directors. ${ }^{72}$ As the Western Cape High Court in Pretorius $v$ PB Meat (Pty) Ltd,${ }^{73}$ Navigator Property Investments (Pty) Ltd $v$ Silver Lakes Crossing Shopping Centre (Pty) Ltd ${ }^{74}$ and Kaimowitz v Delahunt ${ }^{75}$ affirmed, in terms of the Companies Act, the "ultimate" power to manage the affairs of a company resides with the board of directors, and not with the shareholders (unless otherwise provided in the Companies Act or the Memorandum of Incorporation of the company). Since the board's power of management is derived from statute and not from the constitution of the company, as was previously the case, it is now to a lesser extent subject to shareholder control. ${ }^{76}$

In contrast, the UK's Companies Act, 2006 does not contain a provision conferring management power on the board of directors. Instead, the distribution of decision-making power between the board of directors and the shareholders is determined by the constitution of the company. Article 3 of the Model Articles for Private Companies Limited by Shares and article 3 of the Model Articles for Public Companies state that "[s]ubject to the articles, the directors are responsible for the management of the company's business, for which purpose they may exercise all the powers of the company". Article 4 of both Model Articles for private and public companies confers on shareholders the power, "by special resolution, to direct the directors to take, or refrain from taking, specified action". In UK company law, the regulation of the internal affairs of the company by means of rules laid down in the company's constitution is known as the contractarian model, as "English

71 See Kershaw 2012: 191-192.

72 Pretorius v PB Meat (Pty) Ltd [2013] ZAWCHC 89 para 25. See, further, on s 66(1) of the Companies Act: Kaimowitz v Delahunt 2017 (3) SA 201 (WCC) paras 12-13; Delport 2011: 250(1)-262(5); Havenga 2013: 262; Esser \& Delport 2016: 8-10; and Oosthuizen \& Delport 2017: 244 .

73 [2013] ZAWCHC 89 para 25.

74 [2014] JOL 32101 (WCC) para 31.

752017 (3) SA 201 (WCC) para 12

76 Havenga 2013: 262. 
model companies" or as the "memorandum and articles" model of companies. ${ }^{77}$ The constitution of this type of corporation is regarded as a contract between all of the shareholders and the company itself. ${ }^{78}$ The fact that it is left to the articles of association to determine the distribution of decision-making power between the board of directors and the shareholders, indicates that, in the UK, the originating power of the company lies with the shareholders acting in general meeting, and not with the directors, and it is, accordingly, a shareholder-centric approach. ${ }^{79}$ The directors are not granted managerial powers by statute, but such powers must come from the shareholders by way of a delegation of authority. ${ }^{80}$ The shareholders may alter the initial distribution of power, which was delegated to the board of directors by the articles of association, by passing a special resolution to amend such articles of association. ${ }^{81}$ This swings the balance of power in the UK in favour of the shareholders, rather than of the board of directors.

The South African Companies Act of 2008 has clearly moved away from the approach regarding the distribution of power to the board of directors adopted by the Companies Act 61 of 1973 and by the UK. Instead, it now follows the approach adopted in the USA. A long-standing principle of corporate law in the USA is that the power to manage the company is conferred on the board of directors by statute. Section 8.01(b) of the Revised Model Business Corporation Act of 1984 ("MBCA") states that corporate powers are exercised by, or under the authority of, the board of directors, and that the business and affairs of the corporation are managed by, or under the direction of, its board of directors. This approach is director-centric and is known as the division of powers model, because the statute explicitly divides powers between shareholders and directors. ${ }^{82}$ This approach does, however, retain flexibility in that default rules may be changed by the company's constitution. ${ }^{83}$ Likewise, section 141(a) of the Delaware General Corporation Law (Title 8, Chapter 1 of the

77 Kershaw 2012: 85-93; Bruner 2013: 35-36; Davies \& Worthington 2016: 65; Oosthuizen \& Delport 2017: 232-233.

78 See s 33(1) of the UK's Companies Act, 2006, which states that the provisions of a company's constitution bind the company and its members to the same extent as if they were covenants on the part of the company and of each member to observe those provisions.

79 Cools 2005: 738-739; Kershaw 2012: 191; Bruner 2013: 32; Oosthuizen \& Delport 2017: 232-233.

80 Kershaw 2012: 191-192; Bruner 2013: 36

81 See s 21 of the UK's Companies Act, 2006, which states that a company may amend its articles of association by special resolution.

82 See Bruner 2013: 36-65; and Davies \& Worthington 2016: 59 for a further discussion of this model.

83 The default rules may be changed in terms of an agreement authorised under s 7.32 of the MBCA or in terms of any limitation in the articles of incorporation permitted by s 2.02(b) of the MBCA. Section 7.32 of the MBCA deals with shareholder agreements and permits such agreements to restrict the discretion or powers of the board of directors. In terms of s 2.02(b)(iii) of the MBCA, the articles of incorporation may set forth provisions not inconsistent with the law on defining, limiting and regulating the powers of the corporation, its board of directors and its shareholders. 
Delaware Code) ("DGCL") states that the business and affairs of every corporation shall be managed by, or under the direction of, a board of directors (except as otherwise provided in its certificate of incorporation). In Aronson v Lewis,${ }^{84}$ the Supreme Court of Delaware emphasised that a cardinal precept of the DGCL is that directors, rather than shareholders, manage the business and affairs of the corporation.

Under the Corporations Act 2001 of Australia, the management of the business of a company is a matter for the company's directors, and shareholders do not possess the power to make management decisions. ${ }^{85}$ Section 198A(1) of that Act states that the "business of a company is to be managed by or under the direction of the directors" ${ }^{86}$ It should be noted, however, that section 198A is a replaceable rule, meaning that it may be ousted or modified by the constitution of the company ${ }^{87}$ In terms of section 198A(2) of the same Act, the powers of the directors may be curtailed by the Australian Corporations Act of 2001 or by the company's constitution. ${ }^{88}$

In accordance with the approach adopted by section 8.01(b) of the MBCA and section 198A(2) of the Australian Corporations Act of 2001, the powers conferred on directors by section 66(1) of the South African Companies Act of 2008 may be curtailed by the latter Act or by the Memorandum of Incorporation of the company. The shareholders may amend the Memorandum of Incorporation by means of a special resolution or by means of any other requirements set out therein. ${ }^{89}$ The shareholders are thus not without power and are able to curtail the powers of the board of directors in the Memorandum of Incorporation, and to amend it by means of a special resolution or by complying with any other requirements set out in the Memorandum of Incorporation regarding its amendment. There are, however, limitations to the exercise of this power by the shareholders in that (i) a special resolution to amend the Memorandum of Incorporation must be proposed by shareholders entitled to exercise at least 10 per cent of the voting rights that may be exercised on the resolution; ${ }^{90}$ (ii) the threshold for passing a special resolution

84473 A $2 d 805$ (Del 1984) at 811.

85 See, further, Massey $v$ Wales (2003) 177 FLR 1 (Austl) at 12.

86 Despite the presence of s 198A(1) in the Australian Corporations Act of 2001, this statute is shareholder-centric to a large degree, as is the position under the company law in the UK, on which Australian company law is historically rooted. For a further discussion of the approach adopted in Australia, see Bruner 2013: 66-77; and Austin \& Ramsay 2015: 1-2.

87 See s 135 of the Australian Corporations Act of 2001 on replaceable rules. In terms of s 135(2), a provision of a section or of a subsection that applies to a company as a replaceable rule may be displaced or modified by the company's constitution.

88 Section 198A(2) of the Australian Corporations Act of 2001 states as follows: "The directors may exercise all the powers of the company except any powers that this Act or the company's constitution (if any) requires the company to exercise in general meeting."

89 See s 16(1) of the Companies Act of 2008.

90 Idem s 16(1)(c)(i)(bb). 
may be increased in terms of section 65(10) of the Companies Act; ${ }^{91}$ and (iii) in terms of section 16(2) of the Companies Act, more onerous requirements to amend a company's Memorandum of Incorporation than that set out in section 16(1)(c)(i) may be specified in the company's Memorandum of Incorporation. Thus, while the shareholders have the power to curtail the powers of the board of directors in the Memorandum of Incorporation and to amend the Memorandum of Incorporation in order to do so, there are some important limitations to the exercise of this power by the shareholders.

To summarise, since the Companies Act of 2008 determines that the power to manage the business and affairs of the company is derived from statute and not from the constitution of the company and that this power no longer needs to be delegated to the board of directors by the shareholders, the power of the directors is subject to shareholder control to a much lesser extent than was the case under the Companies Act 61 of 1973. The new Companies Act has moved away from the contractarian model adopted in the UK, to the division-of-powers model adopted in the USA and Australia in that the allocation of powers is sourced in legislation, save where it is changed by the constitution of the company. It is evident that under the Companies Act, the balance of power has shifted away from the shareholders and that it now lies in favour of the board of directors.

\section{The separation of ownership and control}

In many small private companies the directors and the shareholders are often the same persons. In larger companies though, as famously documented by Berle and Means in their landmark study in 1932, ${ }^{92}$ ownership and control of companies do not vest in the same persons. Berle and Means argue that ownership and control of a large company are split, in that the control of a company vests in the hands of the managers of the company - being the board of directors - while "ownership" of the company vests in the shareholders. ${ }^{93}$ The effect of the split in ownership and control is that a large body of shareholders has been created who exercise virtually no control over the wealth that they have contributed to the enterprise, while the ownership

91 Under s 65(10) of the Companies Act, a company's Memorandum of Incorporation may permit a different percentage of voting rights to approve any special resolution or one or more different percentages of voting rights to approve special resolutions concerning one or more particular matters.

92 Berle \& Means 1947.

93 Idem at 4. The divorce of ownership from control is the central theme in this classic work of Berle and Means. Written in 1932, Berle and Means envisaged that, over time, there would be an increase in the size of the modern corporation and in the concentration of the economy, leading to a growing dispersion of share ownership and an exaggerated separation of ownership and control. See, further, Hill 2000: 39; Esser \& Havenga 2008: 74; Steyn \& Stainbank 2013: 316; French, Mayson \& Ryan 2015: 433-434; Austin \& Ramsay 2015: 238; and Davies \& Worthington 2016: 412-413. 
interest held by the controlling group, being the directors, is only a decidedly small fraction of the total ownership of the company. ${ }^{94}$

It is important to note at the outset that it is misleading to describe the shareholders as the "owners" of the corporation. Shareholders do not "own" a company; instead, they own shares in the company, which gives them certain legal rights. The property and assets of the company belong to the company itself and not to the shareholders. ${ }^{95}$ While a shareholder may be financially interested in the success or failure of a company because he or she is entitled to a share in the distribution of the surplus assets when a company is liquidated, this does not mean that he or she has any legal right or title to any assets of the company. ${ }^{96}$ It may be that in small private companies where one shareholder or a restricted number of shareholders hold the shares in the company, such shareholders would exercise more control over the company compared to a public company, in which the shareholding is widely dispersed. It would nonetheless be both factually and legally incorrect to refer even to these shareholders as "owners of a company". ${ }^{97}$ The "shareholder/ownership" model was the basis of Berle and Means' work and much of the work that succeeded it, and continues to command much support in practice..$^{98}$ For purposes of this article, the metaphor of shareholders as the "owners" of the company will be used. However, one must bear in mind that this metaphor is not legally or factually accurate, because the owners of the capital of the company are not the owners of the company itself.

For decades, large public companies have issued increasing numbers of shares in order to raise capital for growth and expansion. This has had the effect of causing fragmentation of share ownership in public companies. Shareholders in large public companies have also become widely dispersed or geographically scattered. In

94 Berle \& Means 1947: 5. On the separation of ownership and control, see, generally, Sullivan 1977: 579; Fama \& Jensen 1983: 301; Pinto 1998: 317-346; Hill 2000: 39; Mongalo 2003: 179-186; Esser \& Havenga 2008: 74; Steyn \& Stainbank 2013: 316; Austin \& Ramsay 2015: 238; French, Mayson \& Ryan 2015: 433-434; Hannigan 2016: 183-186; and Esser \& Delport 2016: 8-10.

95 Dadoo Ltd v Krugersdorp Municipal Council 1920 AD 530 at 550-551; Macaura v Northern Assurance Co Ltd [1925] AC 619 (HL (Ir)); Stellenbosch Farmers' Winery Ltd v Distillers Corporation (SA) Ltd 1962 (1) SA 458 (A) at 471-472; The Maritime Trader [1981] 2 Lloyd's Rep 153 (Adm); Francis George Hill Family Trust v South African Reserve Bank 1992 (3) SA 91 (A) at 102; The Shipping Corporation of India Ltd v Evdomon Corporation 1994 (1) SA 550 (A) at 565-566; Hughes $v$ Ridley 2010 (1) SA 381 (KZP) para 22; Prest v Prest [2013] 1 All ER 795 (CA) para 101.

96 Stellenbosch Farmers' Winery Ltd v Distillers Corporation (SA) Ltd 1962 (1) SA 458 (A) at 471-472.

97 Stout 2007: 804; Mongalo 2004: 98.

98 Ferran 1999: 131-132. See, generally, Stigler \& Friedland 1982: 237; Hill 2000: 39; Bratton 2001: 737-741; Mongalo 2003: 184-186; Esser \& Havenga 2008: 74; Steyn \& Stainbank 2013: 316; French, Mayson \& Ryan 2015: 433-434; Austin \& Ramsay 2015: 239; and Davies \& Worthington 2016: 412-413. 
general, the larger the company, the greater the probability that its ownership will be diffused among a multitude of individuals. ${ }^{99}$ Thus ownership and wealth have come to reside less and less in one person. ${ }^{100}$

As Berle and Means explain, ownership of wealth without appreciable control, and control of wealth without appreciable ownership, appear to be the logical outcome of corporate development. ${ }^{101}$ This has the effect that no single shareholder or group of shareholders is able to exercise effective control over the directors. In a large public company, and particularly in a listed company, each shareholder usually owns only a minute fraction of the shares in a company, which means that no one shareholder is in a position to exert control of the company by way of voting in shareholders' meetings. ${ }^{102}$ Thus the power and responsibility of ownership is in effect transferred to a separate group who, in reality, have true control. ${ }^{103}$

The separation of ownership and control creates a potential divergence between the interests of the shareholders and the directors, and leads to the problem that the directors do not necessarily act in the best interests of the shareholders when they manage a company. ${ }^{104}$ This goal-divergence problem is referred to as the "agency problem" or as "agency costs". ${ }^{105}$ In large companies, the principals are not capable of exercising day-to-day control over the affairs of the company. Accordingly, they appoint directors to act as their agents, but, because the ownership of a company is separated from its control, the interests of the principals and the agents are not identical. The directors may well pursue activities that benefit themselves rather than the shareholders of the company. In order to limit the activities of the agent that serve to favour his or her own interests, the principal will establish appropriate incentives for the agent, and incur monitoring costs, which are aimed at limiting the aberrant activities of the agent. ${ }^{106}$

99 Berle \& Means 1947: 52.

100 Idem at 69.

101 Ibid.

102 Mongalo 2003: 184.

103 Berle \& Means 1947: 68.

104 Esser \& Havenga 2008: 76

105 From an economic perspective, shareholders are regarded as the "principals" and directors are regarded as the "agents". From a legal perspective, although the relationship of a director to a company is, in some respects, analogous to that of an agent, this description is not entirely accurate in law. Directors are analogous to agents in that they act for the benefit of another person, being the company, and when they contract on behalf of the company they do not incur liability unless they act outside their power, or expressly or impliedly assume liability. In Robinson v Randfontein Estates Gold Mining Co Ltd 1921 AD 168 at 216-217, the then Appellate Division stated that while it is true that the board of directors is the agent of the company to manage its affairs, each individual director is not as such an agent of the company. See, further, on the agency problem, Jensen \& Meckling 1976: 309; Fama \& Jensen 1983: 301; Roach 2001: 11; Mongalo 2003: 186; Kershaw 2012: 171-188; Steyn \& Stainbank 2013: 317; Austin \& Ramsay 2015: 239. 106 Jensen \& Meckling 1976: 308. 
The concept of separation of ownership and control, as advocated by Berle and Means in 1932, has been strongly influential in analysing the structure and inner workings of a company. However, in modern times, certain qualifications to this concept may be required. For instance, it may be too simplistic to assume that there is necessarily complete separation of ownership and control in all large public companies, such as where the founders of a company retain a large proportion of the company's share capital after the company has been listed and are thus still able to exercise effective control over the company in their capacity as shareholders. ${ }^{107}$ Herman argues that Berle and Means overstated the loss of power of the shareholders and the separation and discretion of managers. ${ }^{108}$

A further qualification to Berle and Means' thesis is the fact that not all shareholders today are small private investors. There has been a significant increase in the number of institutional investors. Institutional investors may hold a sufficiently large shareholding in a company to be able to influence directors directly, and therefore to have a potentially strong monitoring role. ${ }^{109}$ If institutional investors were to act together and share agency costs, they would be a powerful monitor of the performance of directors. ${ }^{110}$ Nonetheless, institutional investors may not be as influential as one might hope, because, in an attempt to diversify their share portfolio and obtain quick financial gains, institutional shareholders generally own shares in a large number of companies and are thus not able to wield real control in any one of the companies in which they invest. ${ }^{11}$

It must be conceded that shareholders in modern times are no longer as powerless as they were during the time of Berle and Means. For instance, individual shareholders in the 1930s did not have an instantaneous means of communication with each other, but in present times, with modern technology, shareholders are able to communicate with each other faster, easier and with less expense, and consequently to act together to exert influence on boards of directors. ${ }^{112}$ For example, under section 63(2) of the Companies Act, unless prohibited by its Memorandum of Incorporation, a company may provide for a shareholders' meeting to be conducted entirely by electronic communication or for one or more shareholders or proxies for shareholders to participate by electronic communication in a shareholders' meeting that is being held in person. Under section 61(10) of the Companies Act, every shareholders' meeting of a public company must be reasonably accessible within South Africa for electronic participation by shareholders in the manner contemplated

107 Ferran 1999: 117-118.

108 Herman 1981: 258.

109 Austin \& Ramsay 2015: 239.

110 Ibid.

111 Mongalo 2004: 99; Keay 2007: 665.

112 Stout 2007: 807. 
in section 63(2) of the same Act, irrespective of whether the meeting is held in South Africa or elsewhere. ${ }^{113}$

The qualifications to the concept of separation of ownership and control as propounded by Berle and Means do not detract from the fact that, in general, and particularly in large companies, there still remains a separation of ownership and control between directors and shareholders. The degree of separation of the ownership and control between directors and shareholders varies from company to company.

\section{Shareholders' power to remove directors from office}

In 1945, the Cohen Committee recommended that shareholders be given "greater powers to remove directors with whom they are dissatisfied". ${ }^{114}$ This recommendation formed the underlying rationale of section 184 of the UK's Companies Act, 1948. ${ }^{115}$ The purpose of that provision was to strengthen shareholder control over management by conferring the power on the shareholders to remove a director from office by means of an ordinary resolution, notwithstanding any provisions in the constitution of the company. ${ }^{116}$

In a similar vein, in order to promote the policy of giving shareholders a greater say in the management of a company and to increase the control that shareholders could exercise over directors, section 69 ter of the SA Companies Act 46 of 1926, in 1952, in an amendment to that Act, conferred on shareholders the power to remove directors from a company. ${ }^{117}$ This latter provision was based on section 184 of the UK's Companies Act, 1948. ${ }^{118}$ The SA Companies Act 61 of 1973, in section 220,

113 Despite shareholders having the option to participate in meetings electronically, in practice they do not necessarily do this. There is still some expense for shareholders to do so, particularly since the access to the means of electronic communication is at the expense of the shareholder or proxy, unless the company determines otherwise (s 63(3)(b) of the Companies Act).

114 Report of the Committee on Company Law Amendment (Cmnd 6659) Jun 1945 para 130.

115 See Prentice 1969: 693. Section 184(1) of the UK's Companies Act, 1948 stated as follows: “A company may by ordinary resolution remove a director before the expiration of his period of office, notwithstanding anything in its articles or in any agreement between it and him: provided that this subsection shall not, in the case of a private company, authorise the removal of a director holding office for life on the eighteenth day of July, nineteen hundred and forty-five, whether or not subject to retirement under an age limit by virtue of the articles or otherwise."

116 Hill 2010: 354.

117 Henochsberg 1953: 151. Section 69ter of the Companies Act 46 of 1926 was inserted in 1952 by s 43 of the Companies Amendment Act 46 of 1952. Section 69ter(1) stated as follows: "A company may by ordinary resolution remove a director before the expiration of office, notwithstanding anything in its articles or in any agreement between it and him: Provided that this sub-section shall not, in the case of a private company, authorize the removal of a director holding office for life on the thirteenth day of June, 1949."

118 Amoils v Fuel Transport (Pty) Ltd 1978 (4) SA 343 (W) at 346-347. 
likewise conferred on shareholders the power to remove directors from a company, notwithstanding the provisions of the company's memorandum and articles of association. ${ }^{119}$

In line with the recommendation of conferring greater powers on shareholders to remove directors with whom they are dissatisfied, the Supreme Court of Delaware in Unocal Corp v Mesa Petroleum $\mathrm{Co}^{120}$ stated that "[i]f the stockholders are displeased with the action of their elected representatives, the powers of corporate democracy are at their disposal to turn the board out". The same court likewise stated in Aronson $v$ Lewis $^{121}$ that a stockholder is not powerless to challenge director action that results in harm to the corporation, and that the machinery of corporate democracy is a potent tool to redress the conduct of a "torpid or unfaithful management".

Furthermore, the shareholders' power to remove directors of a company enhances the ability of shareholders to control the disposition of their investment in the company. ${ }^{122}$ Additionally, it serves to enhance the accountability of directors. If shareholders have removal rights, directors would know that the shareholders may exercise their right to remove them from office if they behave in an incompetent manner or engage in self-serving, opportunistic behaviour. ${ }^{123}$ Since directors exercise significant discretion over the affairs of the company, it is important for them to have a reason to serve the interests of shareholders. ${ }^{124}$ The threat of removal by the shareholders would provide directors with such a strong reason to serve the interests of the shareholders. ${ }^{125}$

In light of the effects of the separation of power and control in a company, the power granted to the shareholders to remove directors is a critical tool in the hands of shareholders; it strikes a balance between the directors' powers of management on the one hand and the shareholders' powers of control on the other. ${ }^{126}$ If the shareholders are displeased with the manner in which the company is being run, they have the right to exercise their ultimate power of control by removing the directors from office. ${ }^{127}$ Therefore, the power conferred on shareholders to remove directors serves to balance the attenuated power of control of shareholders with the power of directors to manage the company, and constitutes a form of corporate democracy. ${ }^{128}$

119 Section 220(1)(a) of the Companies Act 61 of 1973 provided as follows: "A company may, notwithstanding anything in its memorandum or articles or in any agreement between it and any director, by resolution remove a director before the expiration of his period of office."

120493 A 2d 946 (Del 1985) at 959.

121473 A 2d 805 (Del 1984) at 811.

122 Bailey 1974: 86.

123 Kershaw 2012: 220.

124 Bebchuk 2007: 680.

125 Ibid.

126 Cartoon 1980: 17

127 Idem at 18

128 Sirodoeva-Paxson 1999: 11. 
The conferral of this power is rooted in the separation of ownership and control (particularly in public companies) and, provided that shareholders choose to exercise these powers, they are of fundamental importance in the control of a company.

It is evident from the above discussion that the underpinning philosophy of our corporate law regime is that the shareholders' right to remove directors from office is both elementary and necessary, and that it is a key provision of modern company law. ${ }^{129}$ Section 71(1) of the Companies Act confers this right on shareholders by stating that a director may be removed by an ordinary resolution adopted at a shareholders' meeting by the persons entitled to exercise voting rights in an election of that director. No reasons are required for the removal of a director by the shareholders. This power granted to shareholders in terms of this provision applies despite anything to the contrary in a company's Memorandum of Incorporation or rules, or in any agreement between a company and a director, or between any shareholders and a director.

\section{Impact of the board's power to remove a director from office}

The conferral of the removal power on the board of directors has had an impact not only on the shareholders of a company, but also on the board of directors itself. The extent of this impact is discussed below.

\section{Impact on the shareholders of the company}

Even though the Companies Act has now also granted the right to remove directors from office to the board of directors, this does not mean that the power of removal has been withdrawn from the shareholders. Section 71(1) of the Companies Act preserves the right of shareholders to remove directors from office. Accordingly, under the same Act, the right to remove a director is exercisable by both the shareholders and the directors. This accords with the reasoning in the US case of Auer $v$ Dressel, ${ }^{130}$ where the New York Court of Appeals held that even if the board of directors of a company is authorised to remove any director, this would not be an abdication by the shareholders of their inherent right to remove the directors, but rather, that it provides an additional method of removing the directors. Were this not so, the court said, the shareholders might find themselves without an effective remedy in a case where a majority of the directors were accused of wrongdoing and would be unwilling to remove themselves from office. ${ }^{131}$

A few examples when it may be beneficial for the board of directors to exercise the power of removal, are:

129 Cartoon 1980: 17.

$130118 \mathrm{NE} 2 \mathrm{~d} 590$ (NY 1954) at 593.

131 Ibid. 
- When the shareholders who wish to remove an incompetent or miscreant director from office do not have a sufficient majority to remove that director from office. ${ }^{132}$

- When the shareholders do not wish to remove a particular director from office despite his or her wrongdoing, because they believe that he or she is bringing in profits for the company, when in fact such director is a liability and is exposing the company to potential legal action.

- When the shareholders fail to remove a director from office because they are not convinced by the reasons advanced by the board of directors to remove the particular director from office.

- When the board of directors suspects that a director is passing on confidential information to a competitor, or is engaged in ethically questionable activity that will reflect poorly on the company, and they do not wish to disclose to the shareholders such wrongdoing by one of their members for fear that this may expose the company to potential legal action. ${ }^{133}$ Such matters ought to be disclosed to the shareholders, but the board may be concerned that if they disclose this information to the shareholders the latter may institute legal action against them. ${ }^{134}$

Despite the merits of conferring the power of removal on the board of directors, such conferment is not consistent with the above-mentioned rationale of originally granting shareholders the right to remove directors, namely to give the shareholders more power over the directors because the separation of ownership and control resulted in attenuated shareholder control. As discussed earlier, conferring on shareholders the power to remove directors from office gives directors a strong incentive to focus on the interests of shareholders. One other effect of conferring the power of removal on the board of directors, is that directors would be inclined to focus on the interests of the board of directors as well, which may have the effect of diluting their incentive to focus only on the interests of the shareholders and to follow the line of action preferred by the shareholders.

In terms of section 66(4)(b) of the Companies Act, the Memorandum of Incorporation of a profit company (other than a state-owned company) must provide for the election by shareholders of at least 50 per cent of the directors and 50 per cent of any alternate directors. The shareholders therefore have a right to appoint at least half of the directors on the board. As a general rule, shareholders may vote for a director in their own interests; they are under no obligation or duty to choose the person most suitable to be a director. ${ }^{135}$ This is because it is well established that a

132 Knight 2007: 362.

133 McConvill 2005: 210.

134 Ibid.

135 See the UK cases of Re Harmer (HR) Ltd [1959] 1 WLR 62 (CA) at 82; and Kuwait Asia Bank EC $v$ National Mutual Life Nominees Ltd [1991] 1 AC 187 (PC) at 221. 
shareholder's right to vote is a proprietary right. ${ }^{136}$ In many instances, the directors appointed by the shareholders are the representatives of the shareholders. If the board of directors were to remove from office one of these shareholder representatives, this would result in the shareholder control over the board of directors being attenuated, and would further shift the balance of power between the board of directors and the shareholders.

It is submitted that the removal of a shareholder representative from the board of directors by the directors would have an effect on the balance of power not only between the board of directors and the shareholders, but also between the shareholders themselves. For instance, if the board of directors removes from office a director who is a representative of the minority shareholders, this would shift the equilibrium between the majority and minority representatives on the board ${ }^{137}$ and consequently between the majority and minority shareholders.

This possible power shift is further exacerbated by the fact that directors have the right to fill vacancies on the board of directors. ${ }^{138}$ If a vacancy arises on the board of directors, it must be filled by a new appointment if the director had been appointed by a person named or determined in terms of the Memorandum of Incorporation, ${ }^{139}$ or by a new election. ${ }^{140}$ The new election must be conducted at the next annual general meeting of the company (if applicable); or in any other case, within six months after the vacancy arose, at a shareholders' meeting called for the purpose of electing a director; or by a written polling of the shareholders who are entitled to vote in the election of that director. ${ }^{141}$ In terms of section 68(3) of the Companies Act, unless the Memorandum of Incorporation of a profit company provides otherwise, the board of directors is empowered to appoint a person - who satisfies the requirements for election as a director - to fill a vacancy on the board and to serve as a director of the company on a temporary basis until the vacancy has been filled by election. During this temporary period, the director so appointed has all the powers, functions and duties and is subject to all the liabilities of any other director of the company. ${ }^{142}$

The board of directors of a profit company may remove a minority shareholder representative from the board and fill the vacancy, albeit on a temporary basis, with a director whom they favour. As the court in the US case of Bruch $v$ National

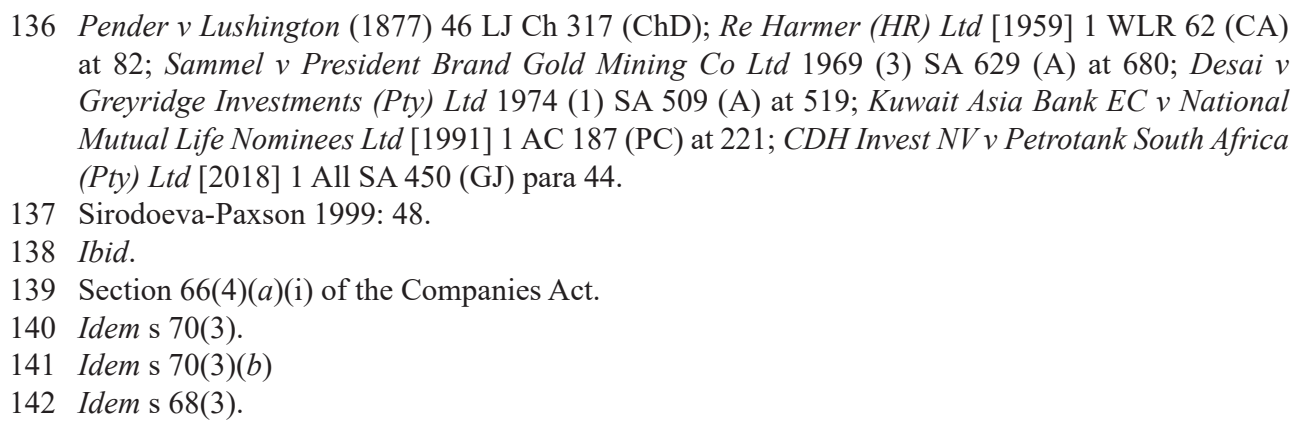
at 82; Sammel v President Brand Gold Mining Co Ltd 1969 (3) SA 629 (A) at 680; Desai v Greyridge Investments (Pty) Ltd 1974 (1) SA 509 (A) at 519; Kuwait Asia Bank EC v National Mutual Life Nominees Ltd [1991] 1 AC 187 (PC) at 221; CDH Invest NVv Petrotank South Africa (Pty) Ltd [2018] 1 All SA 450 (GJ) para 44.

137 Sirodoeva-Paxson 1999: 48.

138 Ibid.

139 Section 66(4)(a)(i) of the Companies Act.

140 Idem s 70(3).

141 Idem s 70(3)(b)

142 Idem s 68(3). 
Guarantee Credit Corp ${ }^{143}$ stated, the "law does not look with disfavor on the policy of securing to minority stockholders a right of representation on the board of directors". Accordingly, as stated above, the power granted to directors to fill vacancies on the board of directors has an impact not only on the balance of power between the directors and the shareholders, but also on the balance of power between the majority and minority shareholders.

\section{Impact on the board of directors}

It is submitted that the board's power of removal of directors also has an impact on the dynamics of the board of directors itself. Such power may have the effect of inhibiting or hindering free and open discussion and debate in board meetings. A director may hesitate to express a dissenting opinion at a board meeting for fear of removal by his or her peers, or a dissident director may simply toe the line in order to preserve his or her position on the board. If directors fail to engage in discussion and debate in board meetings, or fail to question decisions to be made with regard to the company for fear of removal, this would negatively impact on the company and on the shareholders. A concern of removal may also create an environment where directors are so intimidated by the risks of removal that they feel stifled and thus refrain from taking high-risk (but potentially profitable) decisions, or from making long-term strategic decisions that would enhance the value of the company but would not necessarily result in an immediate return of profit. ${ }^{144}$

Directors have a fiduciary duty to observe good faith towards the company, and in discharging that duty they must exercise an independent and unfettered judgement, and make decisions with the best interests of the company in mind. ${ }^{145}$ Should directors simply toe the line for fear of removal and so fail to express controversial or dissenting opinions, they could be in breach of these fiduciary duties.

Knight argues that, while a fear of removal is an important concern, directors are not likely to remain on a board without attempting to contribute to board deliberations, on account of their fiduciary duty to act in the best interests of the

143116 Atl 738 (Del Ch 1922) at 741.

144 Olson 2007: 782.

145 Shuttleworth v Cox Brothers \& Co (Maidenhead) Ltd [1927] 2 KB 9 (CA) at 23; Re Smith \& Fawcett Ltd [1942] Ch 304 (CA) at 306; Boulting v Association of Cinematograph Television and Allied Technicians [1963] 1 All ER 716 (CA) at 723; Charterbridge Corporation Ltd v Lloyd's Bank Ltd [1970] Ch 62 (ChD); Fisheries Development Corporation of SA Ltd v Jorgensen; Fisheries Development Corporation of SA Ltd v AWJ Investments (Pty) Ltd 1980 (4) SA 156 (W) at 163; Fulham Football Club Ltd v Cabra Estates Plc [1992] BCC 863 (CA); Neptune (Vehicle Washing Equipment) Ltd v Fitzgerald (No 2) [1995] 1 BCLC 452 (ChD); Regentcrest Plc (in liquidation) v Cohen [2001] 2 BCLC 80 (ChD) at 105; Extrasure Travel Insurances Ltd $v$ Scattergood [2003] 1 BCLC 598 (ChD) at 618-619; Liwszyc v Smolarek (2005) 55 ACSR 38 (Austl) at 46-47; Da Silva v CH Chemicals (Pty) Ltd 2008 (6) SA 620 (SCA) para 18. 
company. ${ }^{146} \mathrm{He}$ further contends that there exists little incentive for the directors who form a majority on a particular issue to rid themselves of a minority director when that director is not in a position to obstruct the workings of the board or to frustrate the will of the majority of the directors. ${ }^{147}$

Nevertheless, in the instances where the Memorandum of Incorporation of a company requires board decisions to be unanimous, the concern of removal may well result in a minority director hesitating to express a dissenting or controversial opinion. While it is conceded that not all decisions taken by the board of directors would require unanimity and that the board of directors is not likely to remove a minority director for expressing a dissenting opinion or for voting against the majority view, the fear of dismissal may nevertheless result in a minority director hesitating to express a contrary view or failing to attempt to convince the majority to change its view even in those circumstances where he or she believes that the majority view is not in the best interests of the company.

Knight further opines that disagreements in the boardroom would usually be resolved in the normal course of events by a board vote with all the directors abiding by the result, and by those directors who do not wish to be associated with the particular course of action agreed upon by the board, simply resigning from office. ${ }^{148}$ However, it is submitted that in many instances, for reasons of status, prestige or monetary rewards, a director would not be willing to resign from the board of directors if he or she does not wish to be associated with a particular course of action agreed upon by the board of directors. While resignation is a difficult step to take for any director, it is an even more difficult step for an executive director who is involved full-time in the day-to-day affairs of the company. ${ }^{149}$ It is accordingly submitted that Knight's suggestion of resignation would not in all instances be either practical or attractive.

The fear of removal from office may further result in a director failing to bring to the attention of the board of directors a suspicion or knowledge of wrong doing

146 Knight 2007: 361.

147 Ibid.

148 Ibid.

149 In Protect a Partner (Pty) Limited v Laura Machaba-Abiodun [2013] JOL 31048 (LC) para 48, the Labour Court stated that executive directors of a company are also referred to as "inside directors". The court further said that executive directors represent the interest of the entity's stakeholders and often have special knowledge of its inner workings, its financial or market position, and its vision and mission. A non-executive director, the court said, is not employed by the entity and does not generally represent any of its stakeholders. The court also held that a typical example of a non-executive director is a director who is the president of a firm or entity in a different industry. For a further discussion of the distinction between executive and non-executive directors, see Re City Equitable Fire Insurance Co Limited [1925] Ch 407 (CA) at 429; Fisheries Development Corporation of SA Ltd v Jorgensen; Fisheries Development Corporation of SA Ltd v AWJ Investments (Pty) Ltd 1980 (4) SA 156 (W) at 165; Howard v Herrigel 1991 (2) SA 660 (A) at 678; and AWA Ltd v Daniels t/a Deloitte Haskins \& Sells (1992) 7 ACSR 759 (Austl) at 867. 
by fellow directors. Of concern is that this power may not only be used by the board of directors subjectively - and not objectively - but also with ulterior motives. Both of these concerns are illustrated in the UK case of Lee $v$ Chou Wen Hsien. ${ }^{150}$ The appellant, Lee, had become suspicious about certain perceived wrongdoings by the chairperson and managing director of the company. His requests for access to various accounts were denied. When he requested that a board meeting be convened so that he could discuss his suspicions and concerns with the board of directors, he received a notice signed by all his co-directors requesting him to resign immediately. In terms of the company's constitution, the effect of such a notice was that the office of the director in question had to be vacated immediately. The appellant was consequently removed from the board of directors. Even though the Privy Council found that the board of directors had acted with ulterior motives in removing the appellant from the board of directors, it nevertheless held that the removal was valid. ${ }^{151}$ In essence, the Privy Council held that, in order to avoid uncertainty in the management of the company pending the resolution of the dispute, it was necessary to hold that bad faith on the part of any one director in removing a fellow board member would not vitiate the removal and would not retain in office the director whose removal was sought. ${ }^{152}$

It is imperative that the board of directors does not abuse its power to remove a director from office. In the US case of Bruch $v$ National Guarantee Credit Corp ${ }^{153}$ the Delaware Court of Chancery was not in favour of granting directors a right to remove a director from office. The general manager of the company had complained to the board of directors that the director in question had been guilty of embezzlement. Without giving the particular director an opportunity to be heard, the board passed a resolution removing him from office. At the trial, the director in question denied all charges of embezzlement. The court held that the various powers exercisable by a corporation are distributed among the directors, officers and shareholders. ${ }^{154}$ The power to remove a director rests with the shareholders and not with the board of directors. ${ }^{155}$ In overturning the removal of the director in question, the court stated that:

To allow directors to frame charges against one of their fellows and then to try and expel him, would open the door to possibilities of fraud which designing men might use to wrest control of corporate affairs from the stockholders, or their sympathetic representatives on the board, and transfer it to those who might seek to grasp the corporation for their own ends. ${ }^{156}$

150 [1984] 1 WLR 1202 (PC). The case was originally heard by the Court of Appeal of Hong Kong.

151 Idem at 1206-1207.

152 Ibid.

153116 Atl 738 (Del Ch 1922).

154 Idem at 741.

155 Ibid.

156 Ibid. 
It is clear that there must be effective safeguards against the abuse of power by the board of directors to remove a fellow director from office. If there are effective checks and balances, the potential for such abuse of power may be contained.

\section{Maintaining the balance of powers with regard to the removal of directors from office}

Section 5(1) of the Companies Act states that the same Act must be interpreted and applied in a manner that gives effect to the purposes set out in section 7. In Nedbank Ltd $v$ Bestvest 153 (Pty) Ltd; Essa v Bestvest 153 (Pty) Ltd, ${ }^{157}$ Gamble J stated that the effect of section 7 of the Companies Act is that courts are now required to adopt a "fresh approach" when assessing the affairs of corporate entities in South Africa. The court further stated that the legislature has pertinently charged the courts with the duty to interpret the Companies Act in such a way that the founding values of the Constitution of the Republic of South Africa, 1996 are respected and advanced, and further, so that the spirit and purpose of the Companies Act are given effect to. ${ }^{158}$

The court also emphasised that one of the purposes of the Companies Act is to balance the rights and obligations of shareholders and directors within companies. ${ }^{159}$ This purpose is contained in section 7(i) of the Companies Act. It is patent from the above discussion that the statutory conferment on the board of directors of the power of removal of a director has shifted the balance of powers between the shareholders and the directors. This shift in the balance is more pronounced in light of section 66(1) of the Companies Act, which confers original power on the board of directors and results in the board being subject to shareholder control to a lesser extent than hitherto. ${ }^{160}$ Arguably, from the director's point of view, the current position under the Companies Act is a preferable "balance", because the power of the directors has been enhanced. This is not necessarily so from the point of view of the shareholders, because their control over the directors has been reduced. It is important for the rights and obligations of the directors and shareholders to be properly balanced so that directors do not abuse their powers and do not neglect the interests of the shareholders. The balance of powers between the shareholders and directors is furthermore crucial so that the shareholders are able to act as an effective counterbalance to the powerful directors. ${ }^{161}$

The question arises whether it is possible to maintain the balance of powers between the directors and the shareholders. It is submitted that, in light of the

1572012 (5) SA 497 (WCC) para 20.

158 Ibid. See, further, Booysen v Jonkheer Boerewynmakery (Pty) Ltd (in business rescue) [2017] 1 All SA 862 (WCC) para 46 where the same court endorsed this approach.

1592012 (5) SA 497 (WCC) para 20.

160 Havenga 2013: 262.

161 Hannigan 2016: 185. 
redistribution of the power between the shareholders and the directors, it is not possible to maintain the power between these organs in the manner that had existed prior to the conferment of the power of removal on the board of directors. The mere conferral of the power of removal on the board of directors, even if such power is not used, impacts on the balance of power between the directors and the shareholders, and on the dynamics between them, because the threat of the power of removal is ever present.

Nevertheless, even if the balance of power between the directors and the shareholders can no longer be maintained to the same extent as prior to the conferment of the power of removal on the board of directors, it is submitted that the proper balance sought by section 7(i) of the Companies Act could perhaps be achieved if the board of directors gives due consideration to the following factors before deciding whether to remove a fellow board member from office:

- The concept of corporate democracy and the inherent rights of shareholders to appoint and remove a director. Before removing a fellow director from office, the board should consider whether the inherent rights of shareholders to remove directors should be honoured, or whether they should be disregarded, particularly where the director in question was appointed by the shareholders and not by the board of directors.

- Whether a fellow director whom the board of directors wishes to remove is a representative of the minority shareholders, and if so, the impact of such removal on the dynamics between the majority and minority shareholders.

- Whether in removing a director from office, the board of directors would be breaching its fiduciary duties or acting with ulterior motives.

- Whether the board of directors is acting openly and transparently at all times and in the best interests of the company when removing a director from office.

The last two factors mentioned above would in any event have to be complied with by the board of directors in removing a fellow board member from office. Yet, as illustrated in the UK case of Lee $v$ Chou Wen Hsien, ${ }^{162}$ boards of directors do sometimes act with ulterior motives in removing a director from office and do not necessarily always act openly and transparently and in the best interests of the company when doing so. It is evident from that case ${ }^{163}$ that even where the directors are in breach of their fiduciary duties when removing a director or where they remove a director with ulterior motives, a court may nevertheless affirm the board's decision and refuse to reinstate the improperly removed director. 


\section{Conclusion}

This article traces the historical division of powers between the board of directors and the shareholders. It further examines the underpinning philosophy of the removal of directors from office. The matter of separation of ownership and control, as famously documented by Berle and Means in 1932, ${ }^{164}$ is examined and the consequences of the split between ownership and control are canvassed. This article further explores the rationale for conferring the power of removal of directors on shareholders. It is argued that, in light of the effects of the separation of power and control in a company, the power conferred on shareholders to remove directors from office strikes a balance between the attenuated power of control of shareholders with the power of directors to manage the company. It is further argued that the shareholders' power of removal is a critical tool in the hands of shareholders: it is a form of corporate democracy and a necessary and key provision of modern company law.

The enactment of section 71(3) of the Companies Act, conferring power on the board of directors to remove another director from office, has now fundamentally shifted the historical balance of power between the board of directors and shareholders, between the shareholders themselves and even among the board of directors themselves. Despite the merits of conferring the power of removal on the board of directors, such conferment is not consistent with the original rationale for giving shareholders the right to remove directors, that is, to give shareholders more power over directors. This is because the separation of ownership and control has resulted in attenuated shareholder control. In an attempt to achieve the proper balance between directors and shareholders, as required by section 7(i) of the Companies Act, to guard against directors abusing their powers and furthermore neglecting the interests of the shareholders, this article makes certain suggestions with regard to containing the redistribution of power between the directors and the shareholders.

\section{Bibliography}

Aickin, KA (1967) "Division of power between directors and general meeting as a matter of law, and as a matter of fact and policy" Melbourne University LR 5(4): 448-464

Austin, RP \& IM Ramsay (2015) Ford, Austin and Ramsay's Principles of Corporations Law 16 ed (Chatswood, NSW, Australia)

Bailey, RG (1974) "Shareholder control over management: The removal of directors" McGill LJ 20: $85-101$

Bebchuk, LA (2007) "The myth of the shareholder franchise" Virginia LR 93(3): 675-732

Berle, AA \& GC Means (1947) The Modern Corporation and Private Property (repr, New York)

Blackman, MS (1975) “Article 59 and the distribution of powers in a company” SALJ 92: 286-290

164 Berle \& Means 1947: passim. 


\section{THE POWER TO REMOVE COMPANY DIRECTORS FROM OFFICE}

Bratton, WW (2001) "Berle and Means reconsidered at the century's turn" J of Corporation Law 26(3): 737-770

Bruner, CM (2013) Corporate Governance in the Common-law World: The Political Foundations of Shareholder Power (New York)

Cartoon, BJ (1980) "The removal of company directors" The J of Business Law: 17-23

Cilliers, HS \& ML Benade (2002) Corporate Law 3 ed (Durban)

Cools, S (2005) "The real difference in corporate law between the United States and continental Europe: Distribution of powers" Delaware J of Corporate Law 30(3): 697-766

Davies, PL \& S Worthington (2016) Gower Principles of Modern Company Law 10 ed (London)

Delport, P (2011) Henochsberg on the Companies Act 71 of 2008 Loose-leaf publication (Durban)

Herman, ES (1981) Corporate Control, Corporate Power: A Twentieth Century Fund Study (Cambridge)

Esser, I-M \& P Delport (2016) "Shareholder protection philosophy in terms of the Companies Act 71 of 2008" THRHR 79: 1-29

Esser, I \& M Havenga (2008) "Shareholder participation in corporate governance" Speculum Juris 22(1): 74-94

Fama, EF \& MC Jensen (1983) "Separation of ownership and control" J of Law and Economics 26(2): 301-325

Ferran, E (1999) Company Law and Corporate Finance (Oxford)

French, D, S Mayson \& C Ryan (2015) Mayson, French \& Ryan on Company Law 32 ed (Oxford)

Goldberg, GD (1970) “Article 80 of Table A of the Companies Act 1948” Modern LR 33(2): 177-183

Grantham, R (1998) "The doctrinal basis of the rights of company shareholders" Cambridge LJ 57(3): 554-588

Hannigan, B (2016) Company Law 4 ed (Oxford)

Havenga, M (2013) “Directors' exploitation of corporate opportunities and the Companies Act 71 of 2008" TSAR: $257-268$

Henochsberg, ES (1953) Henochsberg on the Companies Act (Durban)

Hill, JG (2000) "Visions and revisions of the shareholder" American J of Comparative Law 48: $39-79$

Hill, JG (2010) "The rising tension between shareholder and director power in the common law world" Corporate Governance: An International Review 18(4): 344-359

Jensen, MC \& WH Meckling (1976) "Theory of the firm: Managerial behavior, agency costs and ownership structure" J of Financial Economics 3(4): 305-360

Keay, A (2007) "Company directors behaving poorly: Disciplinary options for shareholders" J of Business Law 6: 656-682

Kershaw, D (2012) Company Law in Context 2 ed (Oxford)

Knight, SJ (2007) "The removal of public company directors in Australia: Time for change?" Company and Securities LJ 25: 351-369

McConvill, J (2005) "Removal of directors of public companies takes centre stage in Australia: An exploration of the contemporary corporate law and governance issues" Corporate Governance LR 1(1): 191-244 


\section{REHANA CASSIM}

Mongalo, T (2003) "The emergence of corporate governance as a fundamental research topic in South Africa" SALJ 120(1): 173-191

Mongalo, T (2004) "The myth of director appointment by shareholders and shareholder activism in listed companies" TSAR 1: 96-114

Olson, JF (2007) "Professor Bebchuk's brave new world: A reply to 'The myth of the shareholder franchise" Virginia LR 93(3): 773-787

Oosthuizen, JS \& PA Delport (2017) "Rectification of the securities register of a company and the oppression remedy" THRHR 80: 228-252

Pinto, AR (1998) "Corporate governance: Monitoring the board of directors in American corporations" American J of Comparative Law 46: 317-346

Prentice, D (1969) "Removal of directors from office" Modern LR 32(6): 693-696

Roach, L (2001) “The paradox of the traditional justifications for exclusive shareholder governance protection: Expanding the pluralist approach" Company Lawyer 22(1): 9-15

Sirodoeva-Paxson, ON (1999) “Judicial removal of directors: Denial of directors' license to steal or shareholders' freedom to vote?" Hastings LJ 50(1): 1-70

Steyn, B \& L Stainbank (2013) "Separation of ownership and control in South African-listed companies" (2013) South African J of Economic and Management Sciences 16(3): 316-328

Stigler, GJ \& C Friedland (1982) "The literature of economics: The case of Berle and Means" $J$ of Law and Economics 26(2): 237-268

Stout, LA (2007) “The mythical benefits of shareholder control” Virginia LR 93(3): 789-809

Sullivan, GR (1977) "The relationship between the board of directors and the general meeting in limited companies" Law Quarterly Review 93: 569-580

\section{Legislation}

\section{South Africa}

Companies Act 46 of 1926

Companies Act 61 of 1973

Companies Act 71 of 2008

Companies Amendment Act 46 of 1952

\section{Australia}

Corporations Act 2001 (Austl)

\section{United Kingdom}

Companies Act, 1862 (25 \& 26 Vict c 89)

Companies Act, 1948 (c 38)

Companies Act, 2006 (c 46) 
Companies Clauses Consolidation Act, 1845 (8 \& 9 Vict c 16)

Companies (Model Articles) Regulations, 2008 (SI 2008/3229)

Joint Stock Companies Act, 1844 (7 \& 8 Vict c 110)

Joint Stock Companies Act, 1856 (19 \& 20 Vict c 47)

\section{United States of America}

Delaware General Corporation Law (Title 8, Chapter 1 of the Delaware Code)

Revised Model Business Corporation Act of 1984

\section{Table of cases}

\section{South Africa}

Amoils v Fuel Transport (Pty) Ltd 1978 (4) SA 343 (W)

Ben-Tovim v Ben-Tovim 2001 (3) SA 1074 (C)

Booysen v Jonkheer Boerewynmakery (Pty) Ltd (in business rescue) [2017] 1 All SA 862 (WCC)

Cape United Sick Fund Society v Forrest 1956 (4) SA 519 (A)

CDH Invest NV v Petrotank South Africa (Pty) Ltd [2018] 1 All SA 450 (GJ)

Da Silva v CH Chemicals (Pty) Ltd 2008 (6) SA 620 (SCA)

Dadoo Ltd v Krugersdorp Municipal Council 1920 AD 530

Desai v Greyridge Investments (Pty) Ltd 1974 (1) SA 509 (A)

Fisheries Development Corporation of SA Ltd v Jorgensen; Fisheries Development

Corporation of SA Ltd v AWJ Investments (Pty) Ltd 1980 (4) SA 156 (W)

Francis George Hill Family Trust v South African Reserve Bank 1992 (3) SA 91 (A)

Howard v Herrigel 1991 (2) SA 660 (A)

Hughes $v$ Ridley 2010 (1) SA 381 (KZP)

James North (Zimbabwe) (Pvt) Ltd v Mattinson 1990 (2) SA 229 (ZH)

Kaimowitz v Delahunt 2017 (3) SA 201 (WCC)

LSA UK Ltd (formerly Curtainz Ltd) v Impala Platinum Holdings Ltd [2000] ZASCA 178, [2000] JOL 6308 (A), 2000 JDR 0187 (SCA)

Navigator Property Investments (Pty) Ltd v Silver Lakes Crossing Shopping Centre (Pty) Ltd [2014] JOL 32101 (WCC)

Nedbank Ltd v Bestvest 153 (Pty) Ltd; Essa v Bestvest 153 (Pty) Ltd 2012 (5) SA 497 (WCC)

Pretorius v PB Meat (Pty) Ltd [2013] ZAWCHC 89

Protect a Partner (Pty) Limited v Laura Machaba-Abiodun [2013] JOL 31048 (LC)

Robinson v Randfontein Estates Gold Mining Co Ltd 1921 AD 168

Sammel v President Brand Gold Mining Co Ltd 1969 (3) SA 629 (A)

Stellenbosch Farmers' Winery Ltd v Distillers Corporation (SA) Ltd 1962 (1) SA 458 (A) 


\section{REHANA CASSIM}

The Shipping Corporation of India Ltd v Evdomon Corporation 1994 (1) SA 550 (A)

Van Tonder v Pienaar 1982 (2) SA 336 (SE)

Wessels \& Smith v Vanugo Construction (Pty) Ltd 1964 (1) SA 635 (O)

\section{Australia}

AWA Ltd v Daniels t/a Deloitte Haskins \& Sells (1992) 7 ACSR 759 (Austl)

Liwszyc v Smolarek (2005) 55 ACSR 38 (Austl)

Massey $v$ Wales (2003) 177 FLR 1 (Austl)

\section{United Kingdom}

Automatic Self-cleansing Filter Syndicate Company Limited v Cuninghame [1906] 2 Ch 34 (CA) Breckland Group Holdings Ltd v London \& Suffolk Properties Ltd [1989] BCLC 100 (ChD)

Boulting $v$ Association of Cinematograph Television and Allied Technicians [1963] 1 All ER 716 (CA)

Charterbridge Corporation Ltd v Lloyd's Bank Ltd [1970] Ch 62 (ChD)

Extrasure Travel Insurance Ltd v Scattergood [2003] 1 BCLC 598 (ChD)

Fulham Football Club Ltd v Cabra Estates Plc [1992] BCC 863 (CA)

Howard Smith Ltd v Ampol Petroleum Ltd [1974] AC 821 (PC)

Re City Equitable Fire Insurance Co Limited [1925] Ch 407 (CA)

In re Yenidje Tobacco Company Ltd [1916] 2 Ch 426 (CA)

Isle of Wight Railway Co v Tahourdin (1883) 25 Ch 320 (CA)

John Shaw \& Sons (Salford) Ltd v Peter Shaw \& John Shaw [1935] 2 KB 113 (CA)

Kuwait Asia Bank EC v National Mutual Life Nominees Ltd [1991] 1 AC 187 (PC)

Lee v Chou Wen Hsien [1984] 1 WLR 1202 (PC)

Macaura v Northern Assurance Co Ltd [1925] AC 619 (HL (Ir))

Marshall's Valve Gear Co Ltd v Manning, Wardle \& Co Ltd [1909] 78 LJ Ch 46 (ChD)

Neptune (Vehicle Washing Equipment) Ltd v Fitzgerald (No 2) [1995] 1 BCLC 452 (ChD)

Pender v Lushington (1877) 46 LJ Ch 317 (ChD)

Prest v Prest [2013] 1 All ER 795 (CA)

Re Harmer (HR) Ltd [1959] 1 WLR 62 (CA)

Re Smith \& Fawcett Ltd [1942] Ch 304 (CA)

Regentcrest Plc (in liquidation) v Cohen [2001] 2 BCLC 80 (ChD)

Salmon v Quin and Axtens Ltd [1909] 1 Ch 311 (CA)

Scott v Scott [1943] 1 All ER 582 (ChD)

Shuttleworth v Cox Brothers \& Co (Maidenhead) Ltd [1927] 2 KB 9 (CA)

The Gramophone \& Typewriter Ltd v Stanley [1908] 2 KB 89 (CA)

The Maritime Trader [1981] 2 Lloyd's Rep 153 (Adm) 
THE POWER TO REMOVE COMPANY DIRECTORS FROM OFFICE

\section{United States of America}

Aronson v Lewis 473 A 2d 805 (Del 1984)

Auer v Dressel 306 NY 427, 118 NE 2d 590 (NY 1954)

Bruch v National Guarantee Credit Corp 116 Atl 738 (Del Ch 1922)

Unocal Corp v Mesa Petroleum Co 493 A 2d 946 (Del 1985)

\section{Reports}

Report of the Committee on Company Law Amendment (Cmnd 6659) June 1945 